\title{
Globalized World and the Facilitative Role of Modern Media and Sources of Communication in the Process of Ijtehad \& Ijma
} \begin{abstract}
Maqbool Hassan *
\end{abstract}
\begin{abstract}
This paper aims to highlight the significance of Media and means of communication and travel in the feasibility of Ijtehad and Ijma in contemporary world. Modern means of communication and transportation have shrunken the world into a global village. Communication of news and information has become very easy. Environment is much feasible for research and investigation as compared to past. The modern print and electronic media can be used as a platform for academic dialogue and exchange of views both nationally and internationally. The invention of press has made secure the knowledge and resources and easy access to them. The invention of computer and information technology have made easy for Islamic Jurist to access the sources of knowledge. They can communicate with each other via telephone and internet; video conference, email, etc., in spite of sitting together at one place. Modern means of transportation and travel also have shrunken the distances. Years and month's traveling has become just an hour's story. Now it is unto us to have ourselves benefited from all these facilities.
\end{abstract}

Keywords: Globalization, Media, Ijtehad, Ijma, Communication, Dialogue.

\section{Introduction}

Islam is a complete code of conduct and guidance for humans irrespective of time and space up to the day of resurrection and the process of 'Ijtehad' is a source to make it compatible with the time. It is a necessary tool for the accomplishment of socio-legal needs of the Muslim society. Today we are facing so many new problems in almost every walk of life, which were not usual in past. As a result of modern scientific, political and social developments

\footnotetext{
${ }^{*}$ Dr. Maqbool Hassan Assistant Professor, Vice Principal, Bahria College Karsaz, Karachi, Pakistan. drmaqboolhassan@gmail.com
} 
multifaceted problems have arisen which demand the answer in the light of Islam and they need to be solved and regularized in the light of Islamic Law.

Islamic Sharia seems quiet in some of the spheres of human life. Here it implies that the Law Giver wants human beings to deploy their own intellect to chart out the laws. There is a process recognized in Islam since the time of Holy Prophet Muhammad (peace be upon him) to solve the new issues for which there are no pre-existing rules laid down in Quran and Sunnah i.e. Ijtehad.

It is an intellectual effort exerted by an Islamic Jurist-the expert of Islamic law remaining in the frame-work of basic sources of Islam i.e. Quran and Sunnah to deduce the rules and regulations for newly arising multifaceted issues regarding life. When this process is carried out by utilizing collective wisdom by many Jurists with unanimous opinion; then this is called as Ijma (Consensus). Ijma is an important mode of Ijtehad and a well-known principle of Islamic Sharia.

\section{Problem Statement}

Today, media and means of communication, transportation and travel have shrunken the world into a global village and people are much interconnected with each other; hence atmosphere is more feasible for Muslim Scholars to hold Ijtehad and Ijma as compared to the past.

\section{Methodology}

It is a qualitative study depending on available literature pertinent to the topic, to be analyzed for reaching a conclusion.

\section{Globalization: A brief Introduction}

Scholars have different views about globalization. Some of them define it in terms of economic and political restructuring of the modern world while some others refer it to the socio-cultural changes. According to Roland Robertson, globalization is:"The understanding of the world and the increased perception of the world as a whole."1 Martin Albrow and Elizabeth King, sociologists, define globalization as;"All those processes by which the peoples of the world are incorporated into a single world society."2 According to Anthony Giddens; "The globalization can be defined as the strengthening of socialrelations throughout the world, linking distant localities in such a way that local 
happenings are formed as a result of events that occur many miles away and vice versa."3

Thus, globalization is the phenomenon by which all parts of the world become linked, socially, economically, politically and technologically through an expanding network of connections i.e. peoples, ideas, capital, services, goods and civilizations etc. There is another term 'globalism' which signifies the ideological features of 'globalization'. Globalization is frequently used as a convenient form to describe the banquet of communication manufacture and linking technologies throughout the world.

In fact, it is the phenomenon of internationalization which describes crossborder relations between countries. It is used as a process of distribution of various objects and experiences to people at all bends of the earth' (e.g. the spread of computing, television, etc.). It is understood as a dynamic frame whereby the social structures of modernity (capitalism, rationalism, industrialism, bureaucratism etc.) are spread the world over, normally abolishing pre-existent philosophies and local autonomy in process. In other way it is the process of de-territorialization or as the blowout of supraterritoriality, where globalization entails a reconfiguration of layout, so that social space is no longer wholly charted in terms of regional places, local distances and national borders.

Due to the enormous increase in information and communication technology, the peoples of the world are becoming more combined into a single global society. No other process has played such a substantial role in linking the whole world as the process of the globalization. It has made the whole world an open area for universal economic, industrial, cultural, political, and social yields without any restrictions whatsoever. The whole globe, through this process, has become like a small village.

In addition to its many negative aspects, globalization also has some positive aspects e.g. economic, political, social and cultural opportunities and possesses tuning concomitant challenges for Muslim World. Certain aspects of globalization have made it easier to communicate the ideas and views pertinent to the religious issues. As Chandra Muzaffar said in his article, "for the first time in history we have the opportunity to convey to humankind as a whole the universal essence of each of our religion. Instead of allowing narrow-minded 
bigots to monopolize the airwaves, why shouldn't our men and women with a universal outlook state their case through the global media infrastructure?"4

\section{Media (Sources of Communication)}

The word Ablagh (ابلاغ) is used for the word 'media' in the Arabic language. It is derived from Balagha بلغ, means to communicate, to reach, to convey and to get and hence the word Ablagh means Communication of any message, news information, and knowledge from one place to another, from one person to another, or to public at large. ${ }^{5}$ As the Holy Prophet (peace and blessings of Allah be upon him) said:

"Do communicate (to others) from me even single sentence." Although Ablagh is an Arabic term itself but Arab Media is using another term Eelaam اعلام for media and sources of communication. Literally it means declaration, to give knowledge or to inform and to tell, etc. ${ }^{6}$ It is the name of dissemination of realities, news ideas and opinions to the public at large. In short media is the name of broadcasting facts and realities, news, and ideas to people from different sources.

\section{Types of Media:}

Media is basically of two types.

\section{(a) Print Media}

It includes all newspapers, magazines, and books etc.

\section{(b) Electronic Media}

It has further three types which are as follows.

i: Sources of Personal Contact: In the present-day mobile phones, internet, email, video conferences, fax, telephone, etc. are included in it.

ii: Audio Sources: It includes radio, tape recorder etc.

iii: Video Sources: It includes television, video, etc.

\section{Short History of Media}

There was no time when people did not try to convey news and information in different ways. Throughout the history, people used one type of media or the 
other, for instance, sometimes messaging through birds, by adopting a loud voice people were using to give different texts and news to each other and even sometimes they used to communicate massages by pasting posters on the walls.

With the emergence of industrial revolution new changes in the media were also occurred. Starting with 1828AC, the experiences started on TV and then stepped forward. Initially there was picture, then sound, and then the movement. After that in 1979AC it reached up to direct telecasting. Similarly, in 1920AC, Radio was invented in the United States. Print media history is also quite old; however, regular print media began in 1665AC. Similarly, in 1969, Internet started, which reached to climax approximately in 1983 AC.

\section{Importance of Media}

Media has now become the most powerful weapon in the world influencing the human heart and mind. It plays an important role to change the thoughts and ideas of the human being throughout the world. After the revolution of media, now there is no single moment whether it is of the day, or night, that human beings remain intact with media from awakening to sleeping whether it is audio or video and it has major impact on thought and ideology of the human beings.

We should also benefit from the scientific development of the present era. Our academic centers, universities, and other institutions can keep in contact by such type of modern media sources. Professor Dr. Yousuf Farooqui writes about contemporary scientific development and especially use of the latest media facilities in favor of Islam as:

"Academicians should take benefit of the scientific development of modern era. There search wings of Council of Islamic Ideology and the apex judiciary of Pakistan should keep them in contact not only the to the academic and research centers within Pakistan but to the whole world by modern internet facilities so that more benefit can be taken by the worldly scholars and intelligentsia. In such a manner we can hold a more strong way of Ijtehad that could lead towards an international consensus (Ijma) also and ultimately strengthen the unity of Muslim Ummah too."7

That is why Orientalists and western intellectuals not only consider the western edification and ideologies to influence the thoughts and ideas of the people but 
also consider media as apowerful weapon. They think that education is only the first step and media is actual source by which people use to learn more whether they are literate or illiterate. They wish to promote their ideology and culture through widespread media so that they could motivate people at large toward west.

\section{Contemporary Media and its role in the process of Ijtehad \& Ijma}

The present era is far more feasible for inquiry and research as compared to the previous one. The invention of 'Press' has made possible the access not only to the widespread knowledge but the primitive scientific books, including the books of Islam, which are available on a large scale not only in their original languages but also in almost all languages. These books can be used in research as well as in different phases of Ijtehad and Islamic Legislation. Thousands of newspapers, magazines and research journals are being published by which researchers and especially Islamic Jurists can communicate and exchange their opinions to each other and by this written discussion they can understand each other's point of view and come up to a unanimous opinion.

The inventions of computer and internet have created possibilities for Islamic Jurists throughout the world to hold a meeting without sitting at a single place. Internet aided-telephone, and mobile phone have made it easier to connect each other irrespective of time and space. Now the concept of the video conference is also common, through which, with the help of a television screen an academic discussion on any issue can be held.

Internet has released an ocean of information, where authentic information about every sector of the world is available on finger tips and thousands of other books are also available on various websites. Islamic Jurists can benefit from them in the juristic inquiry and legislation process. Similarly, the invention of mobile phone has also paved the way for Islamic Jurists throughout the world to connect with each other via call and messaging. Landline phones and Fax Machine messaging is again an additional facility.

Radio and TV are also helpful in this regard. Many academic and religious discussions can be held on radio and TV to propagate ideas and to get consent upon any matter. Because social and academic development is a gradual and 
durable process that sometimes takes several years and centuries. It is also a requirement to propagate and publicize the idea first for the consideration of scholars of different fields so that they may reach to any conclusion. Media play an important role in the process of propagation and formulating of a final unanimous opinion.

\section{Contemporary sources of transportations and their facilitative role in the process of ijtehad \& ijma}

Sources of transportations mean sources of traveling from one place to another, and transportation of goods. In the past people used to travel thousands of miles from one country to another either as pedestrians or by horses and camels and took several months to reach.

Allah Almighty may give a superior position to the 'Compilers of Ahadith' (Mohaddiseen) as they traveled thousands of miles and reached to thousands of people irrespective of seasonal intensity and affects and met millions of people and heard from them Hadith-e-Rasool. They spent many years in researching Ahadith. After the hard works, they collected the stock of Ahadith and on the other hand today we are reading and taking guidance from them by sitting in an air conditioned room. In that era, it was not possible for Islamic community and scholars of different cities, and countries become together at one place, to discuss any issue and to reach a consensus and unanimous opinion. Contrary to that era, it is much easier to do so in the modern times.

Innovation of airplane has brought revolutionary changes in travel facilities, and it has made the months and year's travel limited to few hours. Now the atmosphere has become completely favorable for collective efforts/Collective Ijtehad in addition to individual efforts/Individual Ijtehad. As Dr. Mohammad Ad-Dasuqi regarding contemporary means of communication \& transportation and feasible atmosphere for Ijtehad and Ijma, said:

"Due to two reasons, modern era demands us to hold 'Collective Ijtehad', the first is irrespective of the home and regions are far away, but it is easy for our Jurists to sit together and secondly this is due to modern means of communication $\&$ transportation." 8

Professor Abdul Jabbar Shakir in reference to Imam Zarkashi regarding feasibility of modern means of communication \& transportation writes, "In the 
modern era, the successorshave more facilities and opportunities to hold Ijtehad process than our predecessors." 9

\section{Conclusion}

From the above discussion it is clear that globalization has an enormous impact on society especially on Muslim Society. Modern media and sources of communication have made the world global village thus minimized remoteness. The sources of communication have now become a powerful weapon in the world, not only affecting and influencing the people's mind but also more supportive for research and investigation. Now there is an easy atmosphere for the solution of problems of the Muslim community as well as restoration of the Muslim World Order ever before.

In Modern era the atmosphere has been completely favorable and helpful for Muslims to have collective efforts for 'Ijtehad' as compared to individual efforts. These modern sources are helpful in the following ways regarding 'Ijtehad \& Ijma'-the process of Islamic legislation;

a. The invention of the press has not only increased the access to the widespread knowledge, but also the primitive scientific books, including the books of Islam, in their original languages and many other languages.

b. The invention of computer and internet have created possibilities for Islamic Jurists throughout the world to hold a meeting hence the atmosphere is more feasible for Ijtehad and Ijma ever before.

c. Print and electronic media are much helpful for academic and religious discussions as well as in propagation of ideas and to get consent over any matter.

d. Development in sources of modern transportation has brought revolutionary changes in travel facilities and has restricted travels of months and days into few hours. Now scholars from different cities, and countries can gather together at one place easily, to discuss any issue and to collect consensus establishing a collective and unanimous opinion.

\section{Recommendations}

a. It is recommended for the jurists of Muslim Ummah, the institutions carrying out the Ijtehad,Muslim Governments and the Muslim Rulers to use the "Collective mode of "Ijtehad" by employing the collective wisdom of the Ummah rather than Individual one. 
b. $\quad$ Do utilize the modern favorable and helpful electronic and print 'Media Sources' as well as the means of communication and transportation in support and incidence of such an important process of Ijtehad \& Ijma the vital and challenging process of Islamic Legislation in the contemporary era.

\section{References}

${ }^{1}$ Robertson Roland. Globalization: Social Theory and Global Culture. Thousand Oaks: SAGE, 1992.

${ }^{2}$ Albrow, Martin, and Elizabeth King. Globalization, Knowledge and Society: Readings from International Sociology. Thousand Oaks: SAGE, 1990.

${ }^{3}$ Giddens, Anthony. The Consequences of Modernity. Münster: LIT Verlag Münster, 1990.

${ }^{4}$ Muzaffar, Chandra. Globalization and religion: Some reflections. Retrieved July 4, 2018. Retrieved from http://www.islamonline.net/English/contemporary/2002/06/Article3.shtml

${ }^{5}$ Ruhi Baalki, Al-Mowrd, Darul-ul-iIm Lil-malaeene, Muassasa litaaleef, waltarjamah wal-Nashr, Bairut, p-25.

${ }^{6}$ Ibid, p-133

${ }^{7}$ Mohammad Yousuf Farooqui. "Ijtehad; Manahaj wal Asaleeb." Islamabad: Sharia

Academy, International Islamic University, p. 41. 2009.

${ }^{8}$ Mohammad Ad-Dasuqi. "Al-Ijtihad al-Al-Jamaei wa Duwar al-Majamee AlFiqhihia Fi Tatbeeqahu." Qatar: Al-Saqafatah Linnashr. p. 134.

${ }^{9}$ Abdul Jabbar Shakir. "Dore-e-Hazar, Ijtehad, Imkanaat wa Sharait aor Iqbal." Weekly Ahl-e-Hadeeth 7 no. 39. 2008. 